\title{
Anchoring Ubuntu Morality
}

\author{
Moeketsi Letseka \\ College of Education, University of South Africa \\ E-mail: letsem@unisa.ac.za
}

\section{Doi:10.5901/mjss.2013.v4n3p351}

\begin{abstract}
This article explores ways in which ubuntu morality might be anchored in the community, the family, and in personhood. It draws on the main tenets of tribal critical race theory (TribalCrit), whose aim is to unmask, expose, and confront continued colonisation within educational contexts and societal structures. The article recognises that Africa is still largely a communal society, and that it is this communalism which defines the peoples' perception of self-interest, their freedom and their location in the social whole. The family is critical as the primary institution of formative moral development, the school of justice, and the medium for the concrete expression of communal values. The central argument of the article is that ubuntu - inclined communities and families are pivotal to the development of personhood given that persons are products of community. In most of Africa personhood is constituted by the interplay between the culturally objectified conception of persons, and the subjectively apprehended aspects of social life through which individuals express their subjectivity in opposition to or in conformity to the conventionally defined roles, rules, and regulations of the habitus. In the last instance the article seeks to insert ubuntu as an indigenous African epistemology in contemporary socio-political and cultural discourses.
\end{abstract}

Keywords: Ubuntu, morality, community, family, personhood, tribal critical race theory (TribalCrit).

\section{Introduction}

In my previous contributions to the debate on ubuntu in the areas of African philosophy and philosophy of education in South Africa I mounted a defence of ubuntu against Penny Enslin \& Kai Horsthemke's (2004) doubts about its viability as a model for citizenship education in African democracies. I argued that ubuntu is a normative concept (a moral theory), a humane notion, and a potential public policy. ${ }^{1}$ Having mounted that defence [successfully, I hope], I subsequently published the sequel in which I lamented the shocking and horrifying incidents of moral indiscretion that appear to have become commonplace in South Africa. ${ }^{2}$ These range from violent crime, premeditated murder, rape, assault, to homophobic attacks and police brutality. These incidents almost made me doubt my own faith in the worth of ubuntu that I had so strongly advocated in my publications. I thought hard and deep about how ubuntu might respond to these incidents of moral indiscretion. Eventually I offered my readers African traditional education and Basotho indigenous education as programmes we might draw on to address the development of the sort of personhood that is necessary for ubuntu moral dispositions. I justified my choice of Basotho indigenous education on the grounds that it is my own native education about which I can write uninhibitedly. I surmised that young people who are initiated into ubuntu morality have the potential to become citizens that are inclined to treating others with justice and fairness at all times.

In this article I grapple with ubuntu morality and how it can be anchored in the community, the family, and in personhood. I shall ground ubuntu morality in the tenets of 'tribal critical race theory' (TribalCrit). Brayboy (2005, p.427) contends that TribalCrit "is rooted in the multiple, nuanced, and historically - and geographically-located epistemologies and ontologies found in Indigenous communities". In my work on ubuntu to which I briefly referred above I sought to rebut attempts mythologise ubuntu and to denigrate its value (Letseka, 2012). Brayboy (2005, p.430) suggests that "much of what TribalCrit offers as an analytical lens is a new and more culturally nuanced way of examining the lives and experiences of tribal peoples since contact with Europeans over 500 years ago". As I will later argue, taking a step back,

1 See Letseka, M. (2012) "In defence of ubuntu", Studies in Philosophy and Education, 31 (1), 47-60.

2See Letseka, M. (2013) "Educating for ubuntu/botho: lessons from Basotho indigenous education", Open Journal of Philosophy, 3 (2), 337-344. 
as it were, 'returning to the source' 3 , is to affirm the value of indigenous epistemologies and to insert them in contemporary socio-political and cultural discourses and paradigms.

I now want to briefly clarify my understanding of some of the terms that I shall use in this article. Starting with 'the family': I must acknowledge from the outset that the notion of 'the family' is porous and constantly shifting. There is such a plurality of what it means that we can ill afford to offer a 'one-size-fits-all' notion of 'the family'. Having said that, there is no doubt that 'the family' [however we conceive of it] is at the epicentre of the development and flourishing of ubuntu moral dispositions. 'The family' has been described as "one outstanding cultural value of the traditional African society" (Gyekye, 1997), a "microcosm of the wider society" (Mbiti, 1975), the "raison d'être of all social co-operation" (Ayisi, 1992), and "the school of justice" (Okin, 1989). In this article I shall refer to 'the family' in its nucleus and its extended senses. I intend this to be more reflective of South Africa's communities in which 'the family' is located. These can be deeply rural, proudly traditional and communal. Or they can be pretentiously suburban, urban and very cosmopolitan whist also still keen to retain some of the aspects that are traditional and communal.

My use of the term 'morality' shall be premised on the assumption that "morality within Africa is that which evolves from the process of living and is grounded in the context of communal life" (Verhoerf \& Michel, 1997, p.394). This assumption resonates with the views of Nigerian-born professor of philosophy at Wellesley College in Massachusetts, USA, Efeany Menkiti (2004, p.324), who argues that in Africa "morality demands a point of view best described as one of beingness-with-others". As Ramose (2003b, p. 382) puts it, "the logic of ubuntu is towards-ness". Thus in South Africa the saying, umuntu ngumuntu ngabantu, or its Sotho variation, motho ke motho ka batho, whose English variation approximates "a person is a person through other persons", is so pertinent to the African life of communal interdependence and ubuntu moral dispositions. My understanding of the term 'disposition' draws on the work of University of Illinois professor of critical thinking and philosophy of science Robert Ennis (1996, p.166), who defines a 'disposition' as "a tendency to do something, given certain conditions". In the context of this article that tendency would be an ubuntu conduct. Elsewhere I have acknowledged the temporal nature of morality (Letseka, 2013). Drawing on Neil Levy's (2004, p. 41) work, I recognised that defining morality was no easy task. However, it is Levy's contention that "a moral system must be devoted, largely if not wholly, to a concern for the welfare of other people". It is his view that "a morality must systematise norms of justice and fairness and prescribe equal treatment for everyone" (Levy, 2004, p.44).

The article is structured around five sections. I start with a brief sketching of the key tenets of TribalCrit. I shall argue that TribalCrit and other critical race theories (CRTs) help to unmask, expose, and confront continuing colonisation within educational contexts and societal structures. Second, I shall tease out the notion of 'community'. Africa is still a communal society, and it is this communalism which defines the peoples' perception of self-interest, their freedom and their location in the social whole (Ake, 1993). Ubuntu holds that community is essential to intersubjectivity, and that a person is incomplete unless he or she maintains an active connection with the society or culture of which he or she is a part. Thus in the African context ubuntu is grounded in a traditional African community where the formative moral development of children is honed. In the third section I shall delineate the notion of the family in its western conception as the 'nucleus' family, and in its African conception as the 'extended' family. I shall argue that the family is not only the microcosm of the wider society, but also a medium for the concrete expression of communal values. In the fourth section I shall sketch conceptions of personhood with a view to arguing that in the African context personhood is socially generated and constituted by the theories, practices, and institutions that a society may deem meaningful to its peculiar experiences. As Masolo (2012, p. 89) succinctly puts it, "personhood is intersubjectively constituted". In the fifth and final section I shall provide some concluding remarks. I now turn to a brief sketching of the tenets of TribalCrit with a view to juxtaposing these with key assumptions of the discourse of ubuntu.

\section{Tribal Critical Race Theory (TribalCrit)}

TribalCrit was introduced by University of Utah scholar of Indigenous American Indian epistemologies Bryan Brayboy (2005). Brayboy (2005, p.441) contends that TribalCrit rooted in the multiple, nuanced, historically and geographically located epistemologies and ontologies found in Indigenous communities (Brayboy, 2005, p.427). He highlights the following nine tenets of TribalCrit (Brayboy, 2005, pp. 429-30).

- Colonisation is endemic to society.

3The notion of 'return to the source' was made prominent by Guinea-Bissauan and Cape Verdean revolutionary leader Amilcar Cabral (1973, p. 61), who argues in his book Return to the Source: Selected Speeches of Amilcar Cabral, that 'return to the source', or 'cultural renaissance' means, among other things, recognition that the masses of the indigenous people who live in the villages are the repository of society's culture, and the only social sector who can preserve and build it up and make history. 
- U.S. policies toward Indigenous peoples are rooted in imperialism, White supremacy, and a desire for material gain.

- Indigenous peoples occupy a liminal space that accounts for both the political and racialised natures of our identities.

- Indigenous peoples have a desire to obtain and forge tribal sovereignty, tribal autonomy, self-determination, and self-identification.

- The concepts of culture, knowledge, and power take on new meaning when examined through an Indigenous lens.

- Governmental policies and educational policies toward Indigenous peoples are intimately linked around the problematic goal of assimilation.

- Tribal philosophies, beliefs, customs, traditions, and visions for the future are central to understanding the lived realities of Indigenous peoples, but they also illustrate the differences and adaptability among individuals and groups.

- Stories are not separate from theory; they make up theory and are, therefore, real and legitimate sources of data and ways of being.

- Theory and practice are connected in deep and explicit ways such that scholars must work towards social change.

Brayboy's (2005, p.430) argues that "the primary tenet of TribalCrit is the notion that colonisation is endemic to society". By colonisation he means that "European American thought, knowledge, and power structures dominate present-day society in the United States". He cites Battiste (2002, p.5), who writes that "Eurocentric thinkers dismissed Indigenous knowledge in the same way they dismissed any socio-political cultural life they did not understand: they found it to be unsystematic and incapable of meeting the productivity needs of the modern world". I shall say more on Eurocentricism below. For now, suffices it to mention that Eurocentrism is a culturalist phenomenon that seeks to universalise Euro-American assumptions and historiographies. Writer $(2008$, p.3) notes that "although a significant role is played by racism, a primary tenet within TribalCrit is the endemic nature of colonisation and its processes in society". She is convinced that TribalCrit offers "the possibility of unmasking, exposing, and confronting continued colonisation within educational contexts and societal structures, thus transforming those contexts and structures for Indigenous Peoples" (Writer, 2008, p.2). It is her contention that critical race theory (CRT) and TribalCrit are ontological and epistemological frameworks that construct multicultural education as social justice' to function as a means to access and understand the 'story' of colonisation of Indigenous Peoples; to understand how colonisation is continuously enacted upon Indigenous Peoples, and to change the enactment of colonisation (Writer, 2008, p.3). For Dana-Sacco (2010, pp. 64-65), TribalCrit focuses on "the endemic nature of colonisation; the marginalisation it creates; and how the dialogic relationship between Indigenous culture, knowledge, and power enables praxis on individual and tribal levels". She defines praxis as "reflection and action directed at the structures to be transformed".

There are parallels between the ideas and intentions of the above proponents of TribalCrit and the ideas and intentions of the proponents of ubuntu, which took centre stage in South Africa in the early 1990s as a result of the Truth and Reconciliation Commission (TRC) (Letseka, 2013, 2012, 2000; Metz \& Gaie, 2010; Metz, 2007; Broodryk, 2003; Ramose, 2003a, 2003b, 1999; Sindane \& Liebenberg, 2000; Tutu, 1999; Sindane, 1994, Shutte, 1994). Let me briefly explain. One of the tenets of TribalCrit that Brayboy (2005) mentions is that "Indigenous peoples have a desire to obtain and forge tribal sovereignty, tribal autonomy, self-determination, and self-identification". The need for tribal sovereignty, tribal autonomy, self-determination, and self-identification can be regarded as a response to colonisation and Eurocenticism. Egyptian Marxist economist Samir Amin (1989) contends that Eurocentrism is a culturalist phenomenon that assumes the existence of irreducibly distinct cultural variants that shape the historical paths of different peoples. It claims that imitation of expression of the Western model by all people is the only solution to the challenges of our time. Thus Eurocentrism implies a theory of world history and, departing from it, a global political project. Amin (1989, p.106) argues that Eurocentrism's manifestations are expressed in the most varied of areas: day-to-day relationships between individuals, political formation and opinion, general view concerning society and culture, and social science. These expressions are sometimes violent, leading all the way to racism, and sometimes subtle. But Amin rejects Eurocentrism. $\mathrm{He}$ charges that Eurocentrism is unable to see anything other than the lives of those who are comfortably installed in the modern world. He finds parallels between Eurocentrism and Nazism, and argues that the latter is the extreme formulation of the thesis of Eurocentrism.

Turkish-born historian and former professor of Duke University Arif Dirlik (2002, p.258) posits that Eurocentricism can be regarded as "a principle for reordering the world's evidence and reorganising the past". Since World War II 
Eurocentricism has been the informing principle in the constructions of history, not just Euro-American historiographies, but in the spatial and temporal assumptions of dominant historiographies worldwide (Dirlik, 2002, p.260). In the same vein Howard University anthropologist S.O.Y. Keita (2002, p.287) argues that Eurocentrism universalised history in such a way that the world as we know it today has become "subject to racialised historiographies and epistemologies". The histories emerging from the nineteenth century onwards, whether written by Europeans or not, were decidedly Eurocentric (Keita, 2002, p.288). And the reason for this is fairly simple. Euro-Americans conquered the world, renamed places, rearranged economies, societies, and politics, and drove to the margins pre-modern ways of knowing space, time, and many other things. Hence the need for TribalCrit and the reassertion of indigenous epistemologies such as ubuntu cannot be overemphasised.

One of Brayboy's (2005, p.434) tenets of TribalCrit is that "TribalCrit problematises the concepts of culture, knowledge, and power and offers alternative ways of understanding them through an Indigenous lens". This way, Brayboy argues, "TribalCrit migrates away from western/European notions of culture, knowledge, and power and moves to notions that have been circulating among Indigenous peoples for thousands of years". South African-born Central Michigan University scholar of indigenous epistemologies Ivy Goduka $(2005$, p.60) compellingly argues that indigenous ways of knowing are by no means "a romanticism and, a nostalgic yearning for the long gone past, or a movement to go back to the 'caves' and 'bushes.' Neither are they rigid understandings of culture as static, archaic, exclusionary, and frozen in space and time". This is because "cultures are dynamic and adaptive, and have evolved over time to integrate other ways of knowing". Indeed as Ghanaian philosopher Kwame Gyekye (1997, pp.217-218) points out, "no human culture is absolutely unchanging, totally refusing to take advantage of possible benefits that often accompany encounters with other cultures. Absolute changelessness is impossible and cannot be considered a necessary condition of any human society".

One of the key strengths of employing any CRT in one's analysis of post-coloniality is that a CRT allows one to mediate the uses of overt or covert power and ideology in order to navigate dominant hegemonic spaces. Elsewhere we debated French philosopher Michel Foucault's 'discourse and power' and I shall therefore not dwell on the issues here (Pitsoe \& Letseka, 2012). Suffices it to mention though that for Foucault (1972, p. 49), discourses are not only about what can be said and thought, but also about who can speak, when, and with what authority. Discourses embody meaning and social relationships, they constitute both subjectivity and power relations; and are "practices that systematically form the objects of which they speak. In addition, discourses are not about objects; they do not identify objects, they constitute them and in the practice of doing so conceal their own invention". Saint Cloud State University sociologist Tracy Ore (2006, p.202) reminds us that "maintaining systems of inequality relies on a foundation constructed of several components. Central to this foundation is the presence of an ideology - a set of cultural values, beliefs, and attitudes that provide the basis for inequality and thus, in part, endorse and justify the interests of the dominant group". In South Africa most of the attempts to denigrate and disparage ubuntu can be regarded as part of the Eurocentric paradigm referred to above whose aim is to reorder the world's evidence, reorganise the past into racialised historiographies and epistemologies. One way of avoiding such reordering and reorganising is by drawing on paradigms such as TribalCrit and CRTs to unmask, expose, and confront racialised agendas.

Another of Brayboy's (2005) tenets of TribalCrit is that "stories make up theory and are, therefore, real and legitimate sources of data and ways of being". Corroborating this particular tenet, I have made a case for the importance of ditśomo-Sotho folk tales or legends to Basotho social philosophy (Letseka, 2013). The ditśomo are orally passed down from one generation to the next and become part of the community's tradition. I drew on David Coplan (1993, p. 92) who argues that like auriterary metaphors, ditśomo are intended to startle untamed meanings from their burrows. They are full of surprises and attacks ranging from the uncanny to the fantastical, with mythical creatures, wild animals, and even wilder humans pursuing improbable stratagems. But at the heart of ditśomo are home truths about the nature of humanity and society.

Finally, Brayboy (2005) argues that tribal philosophies, beliefs, customs, traditions, and visions for the future are not only central to our understanding of the lived realities of Indigenous peoples, they also illustrate the differences and adaptability among individuals and groups. Juxtaposing the notion of ubuntu with the above expositions of TribalCrit raises fascinating socio-cultural dynamics. For instance, Ramose (2003a) argues that understood as be-ing human (humanness); a humane, respectful, and polite attitude towards others, "ubuntu is the root of African philosophy. The being of an African in the universe is inseparably anchored upon ubuntu" (Ramose 2003a, p.270). In what French philosopher Jean Paul Sartre (2003) calls being-with-others, in his book Being and Nothingness: An Essay on Phenomenological Ontology, we discover ourselves not in conflict with the other but in community with him. For Sartre (2003, p.435), the 'we' includes a plurality of subjectives which recognise one another as subjectivities. The 'we' is a 
particular experience which is produced in special cases on the foundation of being-for-others in general. The being-forothers precedes and founds the being-with-others (Sartre, 2003, p.436). Back to Ramose (2003a, p.271), it is his contention that ubuntu "is the wellspring flowing with African ontology and epistemology. If these latter are the basis of philosophy, then African philosophy has long been established in and through ubuntu". He further argues that "in this sense, ubuntu is the basis of African philosophy". It can therefore be reasonably inferred that a more nuanced understanding of indigenous epistemologies is critical to reasserting their underlying assumptions and principles against any attempts to disparage and negate their socio-cultural worth. I now turn to the place of ubuntu morality in communities.

\section{Communities and Ubuntu Morality}

Some thirteen (13) years ago I published a chapter titled "African philosophy and educational discourse", 4 in which I attempted to develop the conceptual tools that would allow me to continue theorising the notion of ubuntu to this day. A recapping of the key arguments of that chapter is now in order. I argued that ubuntu has normative implications in that it encapsulates moral norms and values such as "altruism, kindness, generosity, compassion, benevolence, courtesy, and respect and concern for others" (Letseka, 2000, p.180). I posited that "the underlying concern of ubuntu (humaneness) is with the welfare of others (Letseka, 2000, p.184). The reason for this is that ubuntu prescribes desirable and acceptable forms of human conduct in a particular community of people (Letseka, 2000, p.186). I challenged those working in the area of African philosophy of education to "clarify the normative aspects of education in the African context", to pose fundamental questions and to reflect on "the fundamental aspects of the essence of ubuntu on human life, encapsulated by the notion of botho or ubuntu, and how this impacts on human conduct, human experience, and conceptions of the good life" (Letseka, 2000, p.190). I underscored that as a general rule, "we are batho or abantu (persons) because we live lives that are consistent with communally accepted and desirable ethical standards". Ramose (2003b, p.380) endorses some of the sentiments raised in the chapter. He argues that "ubuntu as a concept and experience is linked epistemologically to umuntu [person]. On the basis of this link umuntu posits ubuntu as its basic normative category of ethics".

As an African, my engagement with the notion of ubuntu is grounded in understandings of a traditional African community where my formative moral development was honed. As Nigerian political economist Claude Ake (1993, p.243) reminds us, "Africa is still a communal society, and it is this communalism which defines the peoples' perception of selfinterest, their freedom and their location in the social whole". This perception manifests in the enduring sense of communal interdependence. In the African context it is a truism that communality and interdependence are complimentary characteristic features of most cultures. Chachine $(2008$, p.74) argues that ubuntu "articulates a view of oneself in the realm of social interdependence". That realm manifests in belonging to, and being grounded in one's community. In the ubuntu conceptual scheme community is "central to the African understanding of person, where the individual is conceived of as attaining the idea of himself or herself in terms of his or her continuing engagement within the web of social relationships". Thus ubuntu implies an interactive ethic in which our humanity is shaped by our interaction with others as co-dependent beings (McCluskey and Lephalala, 2010; Cornell and van Marle, 2005).

Let me further amplify this idea of African communal interdependence. Libin (2003, p.126) contends that the philosophy of ubuntu holds that "community is essential to subjectivity. That is, a person is incomplete unless he or she maintains an active connection with the society or culture of which he or she is a part". Menkiti (2004, p.326) argues that in the stated journey of the individual toward personhood "the community plays a vital role both as catalyst and as prescriber of norms. The idea is that in order to transform what was initially biologically given into full personhood, the community, of necessity, has to step in, since the individual, himself or herself, cannot carry through the transformation unassisted". In this regard Kenyan theologian and philosopher John S. Mbiti (1972) is credited for giving prominence to the maxim: I am, because we are; and since we are, therefore I am. Put simply, "to 'be' is to belong" (Chachine, 2008, p. 74). Mbiti $(1989$, p.106) contends that in the African communal life "the individual cannot exist alone except corporately. She owes her existence to other people, including those of past generations and her contemporaries". Endorsing Mbiti's maxim above Ghanaian-born American philosopher at Princeton University, USA, Kwame Anthony Appiah (2004, p.540) argues that "the African asks always not 'who am I?' but 'who are we?', and 'my' problem is not mine alone, but 'ours'". For Goduka (2000, p.71), this is in stark contrast to a Eurocentric view of humanity that is expressed by Rene Descartes in his maxim: "I think, therefore I am", which is "a concept of self that is based on solipsism - a theory which asserts that only the self exists and can be proven to exist; and that the self is abstract and totally individually defined". Ironically the

\footnotetext{
${ }^{4}$ See Letseka, M. (2000) "African philosophy and educational discourse", in Phillip Higgs., Zola Vakalisa, Tyobeka Mda, \& N'Dri AssieLumumba (eds.), African Voices in Education, Juta: Cape Town, pp.179-193.
} 
above- sketched traditional African feature of communal interdependence resonates with the views and thoughts of some western liberal philosophers and cultural commentators. For instance, in his classic book, Four Essays on Liberty, British liberal philosopher Isaiah Berlin (1969, p.124) writes that "men are largely interdependent that no man is so completely private as never to obstruct the lives of others in any way". While American educationist and philosopher John Dewey $(1916$, p.143) remarks that "what one is as a person is what one is as associated with others, in a free give and take intercourse". In the same vein the opening lines of English poet John Donne's famous poem 'No Man is an Island' encapsulate the communality and interdependence that this section is arguing:

"No man is an island,

Entire of itself.

Each is a piece of the continent, A part of the main".

For Verhoef \& Michel (1997, p.395), "in all African societies an orientation exists towards a communal way of life, an understanding grounded in the belief that an individual is naturally connected to, as opposed to separated from, others and the universe". Thus in view of the tacit knowledge that in Africa communities are constituted by families we cannot hope to theorise the notion of 'the community' without unpacking the deeper nuances of the notion of 'the family'. In the next section I briefly highlight conceptions of the family from an African perspective - as the extended family, and from a western point of view - as the nucleus family. However, and notwithstanding these variations, there is consensus that the family is the primary institution of formative moral development for children. Consistent with Ake's (1993) view above that Africa is still a communal society most of South Africa remains vastly rural and communal. And it is in these rural, communal and interdependent parts of the country where the 'extended family' thrives and flourishes. Even in families that have moved to the cities and become urban and cosmopolitan there will still be practices that have their roots in the rural and communal backgrounds. For instance, it is not unusual to witness a sacrificial ceremony in a suburban cosmopolitan area during which an African family appeals to the ancestors to be cleansed of perceived misfortune, or implores the ancestors for more blessings. I now briefly touch on the notion of family as the institution of formative ubuntu morality.

\section{The family and ubuntu morality}

My stance in this article is that 'good moral conduct' should emanate from the family. As Ramose (2003, p.385) notes, "the family is as old as humanity. Yet, what this means precisely differs from one culture to the other". For example, on the one hand in most western cultures the 'family' is conceived of as a 'nucleus' family - confined to the couple and its offspring. On the other, in most African cultures the family is conceived of as the 'extended' family, which embodies "a broad spectrum of personal associations between great-grand parents, grandparents, fathers, mothers, uncles, aunts, children (sisters, brothers, cousins, nephews, and nieces), a host of maternal and paternal relatives, as well as the departed members" (Mbiti, 1975, p.176). The family has been described as an "outstanding cultural value of the traditional African society" (Gyekye, 1997), as "the school of justice" (Okin, 1989), and as "a microcosm of the wider society" (Mbiti, 1975). Let me elaborate. Gyekye (1997, pp.292-293) argues that the family is "the medium for the concrete and spontaneous expression of communal values such as love, caring, cohesion, solidarity, interdependence, mutual sympathy, responsibility and helpfulness". Ghanaian anthropologist Eric Ayisi (1992, p.69) cogently sums this up in his observation that in Africa the "family forms the raison d'être of all social co-operation and responsibility".

In her book, Justice, Gender, and the Family, American liberal feminist political philosopher Susan Moller Okin $(1989$, p.17) describes the family 'a school of justice'. She argues that it is in the family where "children can learn to develop the sense of justice they will require as citizens of a just society". For Okin (1989, p.22), "the family is the primary institution of formative moral development. And the structure and practices of the family must parallel those of the larger society if the sense of justice is to be fostered and maintained". Notice the similarity between Okin's views here with Ayisi's (1992) contention that family is 'the microcosm of the wider society". While Okin (1989, p.14) recognises that the family is "currently the linchpin of the gender structure", and "must be just if we are to have a just society", she is critical of the fact issues of gender justice within the family have been almost entirely ignored by traditional philosophers and political theorists. Okin $(1989$, p.22) concludes by issuing the most succinct statement on the family with which I couldn't agree more:

"A society that is committed to equal respect for all of its members, and to justice in social distributions of benefits and responsibilities, can neither neglect the family nor accept family structures and practices that violate these norms, as 
do current gender-based structures and practices. It is essential that children who are to develop into adults with a strong sense of justice and commitment to just institutions spend their earliest and most formative years in an environment in which they are loved and nurtured, and in which principles of justice are abided by and respected".

However, I should mention that the notion of 'the family' is porous, contested and constantly shifting, and might not, therefore be spoken of, or written about as if it is homogenous, uncontested, and therefore unproblematic. For instance, in South Africa, as is probably the case elsewhere, there is a bourgeoning phenomenon of child-headed families due to the HIVIAIDS pandemic which has resulted in fathers and mothers dying prematurely, leaving behind elder children with the responsibility for looking after their younger siblings (Amoateng \& Heaton, 2007; Skinner \& Davids, 2006). There is also the enduring phenomenon of single parent families, whether it is a single divorced father, a single divorced mother, or a single widowed parent (Steyn \& van Zyl, 2009). Then there are same-sex-headed families, whether by lesbians or gay men (Reddy, Sandfort \& Rispel, 2009).

Ore (2006, p.211) cautions that "as a primary social institution, the family is central to maintaining systems of oppression and privilege based on race, class, gender, and sexuality". She argues that because the family "is so closely connected with other social institutions, such as the state and the economy, the structure of the family significantly influences and is influenced by the structure and actions of these institutions". My own view is that these subtle nuances and undercurrents call for a more sober and calculated engagement with the notion of 'the family' and the sorts of persons that should populate it. To that end, in the penultimate section below I briefly explore notions of personhood that the above conceptions and descriptions of the family ought to develop, groom and release into the wider society.

\section{Personhood and Ubuntu Morality}

There is a symbiotic relationship between personhood, family and community. On the one hand Nigerian-born expert in Africana Studies at Birmingham University, New York, Nkiru Nzegwu (2004, p.422) argues that "personhood necessarily evolves in the nexus of family. The idea of an individual is intelligible only as a member of a family. In other words, a person cannot be an agent capable of self-defined and self-defining choices without family situatedness". On the other hand, University of the West Indies scholar John Tunde Bewaji (2004, p.396) contends that "the wellspring of morality and ethics in African societies is the pursuit of a balance of individual, with communal wellbeing. It is not unusual to get the impression that African cultures extol the virtues of community, that moral obligations are primarily social rather than individual". While in this article I have presented separate sections on the community, the family, and now on the notion of personhood, this was necessary for the purpose of mounting a structured argument. Conceptually, the three complement one another because they are mutually inclusive.

Kenyan philosopher Dismas Masolo (2010) provides a useful articulation of personhood and morality in the African context in chapters four (4) and five (5) of his book Self and Community in a Changing World. Briefly, with respect to personhood Masolo (2010, p.154) operates from the premise that "persons are products of community". He makes a case for "the biological constitution of humans as a necessary but not sufficient basis of personhood, because human beings require gradual socio-genic development to become persons" (Masolo, 2010, p.156). It is his contention that "personhood is constituted by the interplay between the culturally objectified perceptions of persons and the subjectively apprehended aspects of social life through which individuals express their subjectivity in opposition to or conformity to the conventionally defined roles, rules, and regulations of the habitus" (Masolo, 2010, p. 218). This then sets the stage for the creation of a link between personhood and morality. Masolo (2010, p.172) writes: "the metaphysics of personhood, the relational nature of the person sheds a new light on how we understand the foundations of morals". This, he argues, "enables us to see the origin of moral principles as emanating not from the idea of an autonomous and transcendent mind that is endowed with the capability of 'discovering' correspondingly transcendental and objective laws and truths of conduct stacked away in the 'objective world of norms' but rather as emanating from the socially conditioned and located persons whose minds are the capacities of their bodily lives and experiences". In this relational understanding of persons, moral principles "emerge when people understand the needs and interests of others at the same level as their own and when they understand the founding and reciprocal nature of the idea of freedom itself". Masolo (2010, p.241) contends that "it is upon recognition of the basic danger that lurks around the rejection of interdependence between people and between individuals and community that the Swahili people say, for example, that 'mkono mmoja haujikuni mgongon' (a hand does not scratch its own back). The dialectic of mutual dependence that this saying alludes to is most evident in how persons and societies constitute each other".

Professor of Philosophy and Vice-Principal of Chancellor College at the University of Malawi, Didier Kaphagawani (2004, p.336) draws on Chichewa, a Bantu language of southern Africa to argue that munthu, a synonym of umuntu 
[person] in Nguni languages, refers to the species of human beings and has universal applicability, and yet when this word is translated as 'person', it involves a socio-centric view of personhood, which varies from one culture to another and from one time to another due to the dynamic nature of culture and society. Kaphagawani's (2004) analysis above links well with the view I advanced in my chapter contribution to the debate on ubuntu to which I referred in the opening lines of section two above. I argued then that motho or umuntu, from which linguistically botho or ubuntu is derived, can be used on a superficial level to refer to a person or an individual. But "when human conduct, captured in the botho or ubuntu (humanness) of a person, becomes an issue, a clear distinction between a person as an ethical person and as an ordinary individual becomes essential". I argued that "motho or umuntu moves to a higher level, where he/she is endowed with desirable moral norms and virtues such as kindness, generosity, compassion, benevolence, and respect and concern for others" (Letseka, 2000, p.186). I concluded that it would be illogical for anyone with botho or ubuntu to respect and show concern for others and also have the inclination to rape because rape is an affront to and is inconsistent with ubuntu moral norms and virtues.

\section{Conclusion}

What I have attempted to do in this article is to explore ways in which ubuntu morality can be anchored in the community, the family, and in personhood. I sketched the main tenets of TribalCrit and argued that the latter helps to unmask, expose, and confront continued colonisation within educational contexts and societal structures. I showed that community is particularly important in South Africa given that Africa is still largely a communal society. This communalism defines the peoples' perception of self-interest, their freedom and their location in the social whole. I argued that ubuntu is a normative concept that encapsulates various moral norms such as 'altruism', 'kindness', 'generosity', 'compassion', 'benevolence', 'courtesy', and 'respect' and concern for others. I showed that the expression umuntu ngumuntu ngabantu, whose English translation approximates "a person is a person through other persons", implies an interactive ethic in which our humanity is shaped by interaction with others as co-dependent beings. In this interaction the family plays a critical role as the primary institution of formative moral development, the school of justice, the medium for the concrete expression of communal values, and the raison d'être of all social co-operation and responsibility. I posited that ubuntu inclined communities and families are critical to the development of personhood given that persons are products of community. Drawing on the work of Dismas Masolo (2010) I argued that personhood is constituted by the interplay between the culturally objectified conception of persons, and the subjectively apprehended aspects of social life through which individuals express their subjectivity in opposition to or in conformity to the conventionally defined roles, rules, and regulations of the habitus.

\section{References}

Ake, C. (1993) "The unique case of African democracy", International Affairs, 69 (2), 239-244.

Amin, S. (1989) Eurocentrism, Zed Books: London.

Amoateng, A. Y., \& Heaton, T. B. (2007) Families and Households in Post-apartheid South Africa: Socio-demographic Perspectives, HSRC Press: Cape Town.

Appiah, K. A. (2004) "African Philosophy and African Literature", in Kwasi Wiredu (ed) A Companion to African Philosophy, Blackwell Publishing: Malden, Massachusetts, pp.538-548.

Ayisi E. O. (1992) An Introduction to the Study of African Culture, East African Education Publishers: Nairobi.

Battiste, M. (2002) Indigenous Knowledge and Pedagogy in First Nations Education: A Literature Review with Recommendations, Indian and Northern Affairs Canada: Ottawa.

Berlin, E. (1969) Four Essays on Liberty Oxford University Press: Oxford.

Bewaji, J. A. I. (2004) "Ethics and morality in Yoruba culture", in Kwasi Wiredu (ed) A Companion to African Philosophy, Blackwell Publishing: Malden, Massachusetts, pp.396-403.

Brayboy, B. M. J. (2005) "Towards a tribal critical theory in education", Urban Review, 37 (5), 425-446.

Broodryk, J. (2002) Ubuntu: Life Lessons from Africa, Ubuntu School of Philosophy: Pretoria.

Cabral, A. (1973) Return to the Source: Selected Speeches of Amilcar Cabral, Monthly Review: New York.

Chachine, I. E. (2008) "Community, justice, and freedom: Liberalism, communitarianism, and African contributions to political ethics", unpublished PhD thesis, Department of Theology, Studies in Faith and Ideologies, Uppsala University, Sweden.

Cornell, D., \& van Marle, K. (2005) "Exploring ubuntu: tentative reflections", African Human Rights Law Journal, 5 (2): 195-220.

Coplan, D. B. (1993) "History is eaten whole: consuming tropes in Sesotho auriture", History and Theory, 32, 80-104

Dana-Sacco, G. (2010) "The Indigenous Researcher as Individual and Collective: Building a Research Practice Ethic within the Context of Indigenous Languages", American Indian Quarterly, 34 (1), 61-82.

Dewey, J. (1916) Democracy and Education, Free Press: New York. 
Dirlik, A. (2002) "History without a centre: reflections on Eurocentrism", in Eckhardt Fuchs \& Benedikt Stuchtey (eds) Across Cultural Borders: Historiography in Global Perspective, Roman \& Littlefield Publishers: New York.

Ennis, R. H. (1996) "Critical thinking dispositions: their nature and accessibility", Informal Logic, 18 (2 \& 3), 165-182.

Enslin, P., \& Horsthemke, K. (2004) "Can ubuntu provide a model for citizenship education in African democracies?", Comparative Education, 40, 545-558.

Goduka, I. N. (2005) "Eziko: Sipheka sisophula. Nguni foundations for educating/researching for sustainable development", South African Journal of Higher Education, 19 (3), 467-481.

Goduka, I. N. (2000) "African/Indigenous philosophies: legitimising spiritually centred wisdom within academy", in Phillip Higgs., Zola Vakalisa, Tyobeka Mda, \& N'Dri Assie-Lumumba (eds) African Voices in Education, Juta: Cape Town.

Gyekye, K. (1997) Tradition and Modernity: Philosophical reflections on the African experience, Oxford University Press: Oxford.

Kaphagawani, D. N. (2004) "African conceptions of a person: a critical survey", in Kwasi Wiredu (ed) A Companion to African Philosophy, Blackwell Publishing: Malden, Massachusetts.

Kant, E. (1947) The Moral Law or Groundwork of the Metaphysic of Morals, translated by H. J. Patton, Hutchinson's University Library: New York.

Keita, M. (2002) "Africa and the construction of a grand narrative in world history", in Eckhardt Fuchs \& Benedikt Stuchtey (eds) Across Cultural Borders: Historiography in Global Perspective, Roman \& Littlefield Publishers: New York.

Letseka, M. (2013) "Educating for ubuntu/botho: lessons from Basotho indigenous education", Open Journal of Philosophy, 3 (2), 337 344.

Letseka, M. (2012) "In defence of ubuntu", Studies in Philosophy and Education, 31, 47-60.

Letseka, M. (2000) "African philosophy and educational discourse", in Phillip Higgs., Zola Vakalisa, Tyobeka Mda, \& N'Dri AssieLumumba (eds.), African Voices in Education, Juta: Cape Town.

Levy, N. (2004) What makes us moral: Crossing the boundaries of biology, One-world Publications: Oxford.

Masolo, D. A. (2010) Self and Community in a Changing World, Indiana University Press: Bloomington and Indianapolis.

Mbiti, J. S. (1989) African Religions and Philosophy, Second Edition, Doubleday: New York.

Mbiti, J. S. (1975) Introduction to African Religion, Heinemann: London.

McCluskey, G., \& Lephalala, M. (2010) "'A person is a person because of others': challenges to meanings of discipline in South African and UK schools", Power and Education, 2 (1), 18-30.

Menkiti, E. A. (2004) "On thee normative conception of a person", in Kwasi Wiredu (ed) A Companion to Africa Philosophy, Blackwell Publishing: Malden, Massachusetts.

Metz, T. (2007) "Towards an African moral theory", Journal of Political Philosophy, 15(3), 321-341.

Metz, T., \& Gaie, J. B. R. (2010) "The African ethic of Ubuntu/Botho: Implications for research on morality", Journal of Moral Education, 39(3), 273-290.

Ore, T. E. (2006) The Social Construction of Difference and Inequality: Race, Class, Gender, and Sexuality, McGraw Hill: Boston.

Pitsoe, V., \& Letseka, M. (2012) "Foucault's Discourse and Power: Implications for Instructionist Classroom Management", Open Journal of Philosophy, 3 (1), 23-28.

Ramose, M. B. (2010) "Learning inspired education", Caribbean Journal of Philosophy, 2(1)

Ramose, M. B. (2003a) "The philosophy of ubuntu and ubuntu as a philosophy", in P. H. Coetzee \& A. P. J. Roux (eds.) Philosophy from Africa: A text with Readings, Routledge: London.

Ramose, M. B. (2003b) "The ethics of ubuntu", in P. H. Coetzee \& A. P. J. Roux (eds.) Philosophy from Africa: A text with Readings, Routledge: London.

Ramose, M. B. (1999) African Philosophy through Ubuntu, Mond Books Publishers: Harare.

Reddy, V., Sandfort, T., \& Rispel, L. (2009) From Social Silence to Social Science: Same-sex Sexuality, HIV\&AIDS and Gender in South Africa, HSRC Press: Cape Town.

Shutte, A. (1994) Philosophy for Africa, UCT Press: Rondebosch.

Sindane, J., \& Liebenberg, I. (2000) "Reconstruction and the reciprocal other: The philosophy and practice of Ubuntu and democracy in African society", Politeia, 19(3), 31 - 46.

Sindane, J. (1994) Ubuntu and Nation Building, Ubuntu School of Philosophy: Pretoria.

Skinner, D., \& Davids, A. (2006) A Situational Analysis of Orphans and Vulnerable Children in Four Districts of South Africa, HSRC Press: Cape Town.

Steyn, M., \& van Zyl, M. 2009. The Prize and the Price: Shaping Sexualities in South Africa, HSRC Press: Cape Town.

Tutu, D. (1999) No Future without Forgiveness, Rider: London.

Verhoef, H., \& Michel, C. (1997) "Studying morality within the African context: a model of moral analysis and construction", Journal of Moral Education, 26 (4), 389-407.

Writer, J. H. (2008) "Unmasking, Exposing, and Confronting: Critical Race Theory, Tribal Critical Race Theory and Multicultural Education", International Journal of Multicultural Education, 10 (2), 1-15. 
